\title{
AN INTRODUCTION AND CRITICAL ASSESSMENT OF SMART CITY DEVELOPMENTS
}

\author{
László GERE ${ }^{\mathrm{a}}$ \\ ${ }^{a} \mathrm{PhD}$ candidate, Doctoral School of Earth Sciences of the University of Pécs, senior researcher, Pallas \\ Athene Innovation and Geopolitical Foundation, H-1014 Budapest, Úri utca 21. Hungary, \\ gere.laszlo@paigeobudapest.hu
}

Cite this article: Gere, L. (2018). An Introduction and Critical Assessment of Smart City Developments. Deturope, 10(3), 33-52

\begin{abstract}
The urban development methods in the $21^{\text {st }}$ century focus more and more on the different kinds of IT solutions which are increasingly embedded in the operation of urban functions. Therefore, great attention has to be paid on them during the planning process. The so-called smart city solutions are of key importance from the cities' social-economic development viewpoint, and together with their rapid spread, their scientific analysis is very important as well.

This article deals with the growing importance of cities in the $21^{\text {st }}$ century. Different factors affect this process. The first one is demographic change, the global increase of urban population. The second factor is the technological revolution, which significantly transforms the operation and understanding of our cities. The third one is the increasing economic role as well as the changing governance issues of cities.

After introducing these background factors of the changing urban environment, the article focuses more on the smart city solutions. Firstly, it deals with the differences and uncertainties of its definition as well as the appearance of the related definitions. Secondly, it introduces the scientific discourse of the topic, to illustrate the most important differences, debates and arguments emerging in relation with the smart city developments. The last part of the article highlights the social development aspects of smart city developments, their role in decreasing social inequalities.
\end{abstract}

Keywords: Urbanization, Urban development, Smart cities, Critical geography, Technology-driven development, Social inequalities

\section{INTRODUCTION}

This article deals with the theoretical aspects of the efficiency of $21^{\text {st }}$ century urban development instruments, and especially with the application opportunities of the technological instruments, as well as the methodological issues and aspects that have to be regarded for implementing successful technology-focused developments.

Urban development issues have become increasingly important globally, because of the increasing economic, social, political and geopolitical role of the cities. Many significant factors affect this process, which will be introduced shortly in the following section. The first one is the urban population growth. According to the official statistics, the share of urban population exceeded $50 \%$ first time in history at the beginning of the $21^{\text {st }}$ century. For the first 
Gere, L.

time in human history, more people reside in urban areas than in rural areas, and in the forthcoming decades this increasing trend seems to be continuing. This population growth leads to the growing economic and political significance of the cities as well. Another important factor is the technological boom, the innovations of the latest industrial revolution, which increasingly transform the operation of the cities, the understanding of that operation, and the overall urban management - not to mention the recently emerged, city-related socialeconomic demands. The growing importance of the urban economic performance as well as the change in urban governance are also among these factors.

After introducing the affecting factors, the article deals with the technological urban development instruments, the so-called smart city solutions in details. It involves the definition uncertainties, appearing in the literature, as well as the introduction of other related concepts. Since smart city developments are implemented through the co-operation of many different areas of expertise, the literature of this topic is very complex and diverse, but in many cases also one-sided. Therefore, the conceptual clarification as well as the underline of the urban development and urban planning point of view is a reasonable aspect to study in relation with this topic.

Following the presentation of the conceptual issues, the article evaluates the technologybased urban development practices. For that purpose, through an introductory literature review, the article would like to illustrate the main questions, arguments and viewpoints of the scientific discourse of smart city developments. Because of the conflicting viewpoints and opinions, this active professional debate also calls the attention for further analysis of this issue.

The final part of the article would like to find an answer to the question how smart cityrelated instruments and aspects would decrease the social-economic inequalities of urban areas, or at least are aware of the effects of the social factors of smart city solutions. This section underlines the importance of the relation between smart cities and smart citizens, as well as the importance of recognizing that aspect, since the next step of this ongoing research focuses on these issues.

\section{CITIES IN FOCUS}

\section{Global demographic, technological, economic and urban management trends}

Townsend (2013), while searching for the answer, why now did the application of smart city solutions start to boom, and why now did this area become so important, he finds three 
Gere, L.

"historical thresholds", and the first is that in 2008 the share of population - first time in history - shifted from mostly rural to mostly urban. Although, cities have always played a significant role in history, definitely not because of their population share. In 1900 only around $13 \%$ of the global population resided in urban areas, in 1950 the share of rural and urban population was $2 / 3$ to $1 / 3$. In the following 6-7 decades rapid urbanization has started, and according to the projections, by 2050 the share observed a hundred years ago will have just turned: $66 \%$ of the population will reside in urban areas and only $34 \%$ will live in urban areas (UN 2015a). All those changes, together with another forecast that by 2050 the number of global population will have reached 10 billion (UN, 2015b), mean that more than 6.5 billion urban residents can be counted instead of the almost four billion today. Since almost 90\% of this growth is happening in Asia and Africa (UN, 2018), cities there are facing huge demands regarding basic infrastructure that could be optimized by smart applications.

In the $21^{\text {st }}$ century we are facing significant technological changes which have already begun shaping our lives. It is the so-called fourth industrial revolution, which (similarly to the previous ones) will fundamentally transform our lifestyles, our ways of working and our social relationships as well. According to the expert of this topic, Klaus Schwab (2016), the scale, extent and complexity of this transformation will surpass any of the previous industrial revolutions. In his writing, Schwab also mentions the impacts of the previous industrial revolutions on production: the first industrial revolution used steam power to mechanize production, the second created mass production with electric power, and the third used electronics and information technology to automate production. Now, the fourth industrial revolution, as continuation of the third, will implement the fusion of different technologies through digital revolution, blurring the lines between the physical, digital and biological areas (Schwab, 2016, p. 2).

Technological innovations are increasingly channeling into the cities' everyday life; this process reached a turning point in 2008 according to Townsend (2013), who says that this date designates a turning point for the whole global civilization owing to three factors: the first one, the demographic shift was already mentioned. The second is that in 2008 for the first time the number of wireless internet users exceeded that of those who connected through cable (or to put it in another way, today more people connect to the internet through mobile devices than traditional desk computers). The third factor is that in 2008 the number of internet-connected devices exceeded the number of "connected" people (and the further growth is exponential); in other words, from this date can we speak about the age of the internet of things (IoT). 
Gere, L.

The technological progress intensifies the already strong economic performance of the cities. Even today, already around $80 \%$ of the global GDP is produced by cities (Dobbs et al. 2011, p. 1), and the distribution of the global economy becomes more concentrated. One of the Mckinsey Global Institute's reports (Dobbs et al. 2011) examines the top 600 urban centres by GDP performance, which produce $60 \%$ of the global GDP today. The report gives a 15-year forecast, its main results are that the geographical centre of gravity continuously shifts to eastern and southern direction, and by 2025, every third cities from the developed world will drop out of the group, and 136 new cities will join from the developing countries, mostly (100 cities) from China. In addition, the forecast underlines that both the total GDP growth and GDP growth per capita of the top 600 cities will exceed the average global growth. In his book, Khanna (2016) also highlights the economic weight of the cities, for example by mapping the GDP-contribution of the capital cities compared to the national GDP in every country, which illustrates well to which extent can only one city contribute to the economic performance of a given country.

In the $21^{\text {st }}$ century, due to the changing circumstances, the construction and operation of the urban governance has also changed significantly. While the post-WWII period's urban policy systems are described with the term urban government, after the political and economic shift of the 1970s, the literature introduced the term urban governance (JelinekPósfai 2013, p. 145). The former, the urban government is a closed, hierarchically constructed governance system, with a few and exactly identifiable participants. The latter, the urban governance's main characteristics are the structural economic change, the limited state involvement, as well as the cities' global competition for investments. The decision-making process in this structure is more flexible, multi-stakeholder, and beside the urban municipality's institutional actors, the role of partnership relations beyond the traditional political sphere (Jelinek-Pósfai 2013, p. 145) and the network-like structures (Tosics 2008, p. 5) become more important.

\section{WHAT DOES SMART CITY MEAN?}

\section{The antecedents of the term}

The smart city concept is one of today's most frequently used buzzwords in urbanism, although its emergence is not even related to the narrowly defined urban development as a profession, and the definition of the term is still unclear. 
Gere, L.

From a historical perspective, it could be said that smart city is no more than the $21^{\text {st }}$ century interpretation of the planned (new)towns. In this sense, the antecedents can be originated back in the $19^{\text {th }}$ century, from Ebenezer Howard's (Howard, 1898) Garden City concept, through the French Eugéne Hénard's vision from the early $20^{\text {th }}$ century about "the cities of the future" (Hénard, 1910), to the vision of the also French urban planner, Le Corbusier. Of course, the roots can be originated far back in history, because ultimately, widely interpreted, any kind of utopian urban development concept can be included here, which are practically as old as humanity.

Looking at the emergence of the smart city concept a little bit closer, we can see that it is definitely related to the spread of digitalization and the internet. In this sense, it has antecedents as well, or in many cases it is used parallel to, or as a synonym for other terms. This includes, inter alia, digital city or intelligent city, that were coined in the 1990s and were used widespread for a long time, as well as many "co-concepts", for instance the information city, innovative city, virtual city, livable city, eco-city, green city and sustainable city (Eremia, Toma, \& Sanduleac. 2017). These labels are mostly given to the certain cities only to enhance their attractiveness, as well as to make them somehow unique, to help them stand out from the other cities, therefore, complex and hardly understandable terms emerge as well (smart-ecocity, smart-sustainable city), or even those strange labels like „wise city“ or „brilliant city“ (Lux Research, 2015, cited by Z. Karvalics, 2016).

Although the use of the term smart city started to spread around a decade ago in the urban development literature (among others), the expression had been coined somewhat earlier (first, not specifically related to cities, but as "smart growth"). According to Harrison and Donnelly (2011), the term started to spread in the late 90s, exactly in relation with a study on smart growth. Then from the middle of the 2000s, many tech-companies (Siemens, 2004, Cisco, 2005, IBM, 2009 etc.) applied the label as a common reference for complex IT systems in urban infrastructure and the operation of public services (Harrison-Donnelly, 2011, p. 2). That time the tech-companies began to create the first divisions dedicated particularly to urban development issues (e.g. IBM Smarter Cities ${ }^{1}$, Siemens Smart City ${ }^{2}$, Microsoft CityNext $\left.{ }^{3}\right)$.

The popularization of the expression is vividly described by Jong, Joss, Schraven, Zhan, and Weijnen (2015) in the article where they summarized their research on the diversity of

\footnotetext{
${ }^{1}$ https://www.ibm.com/smarterplanet/us/en/smarter_cities/overview/

${ }^{2} \mathrm{http}: / / \mathrm{w} 3$. siemens.com/topics/global/en/sustainable-cities/Documents/smart-cities-en/index.html\#/en/home

${ }^{3}$ https://enterprise.microsoft.com/en-us/industries/citynext/
} 
urban labels. There the authors analyzed keywords ${ }^{4}$ from the international scientific literature within a particular time period. The results are concluded in this figure below (Fig. 1):

Figure 1 Change in the occurrence of twelve urban "labels" in scientific publications of the Scopus database between 1996 and 2013.

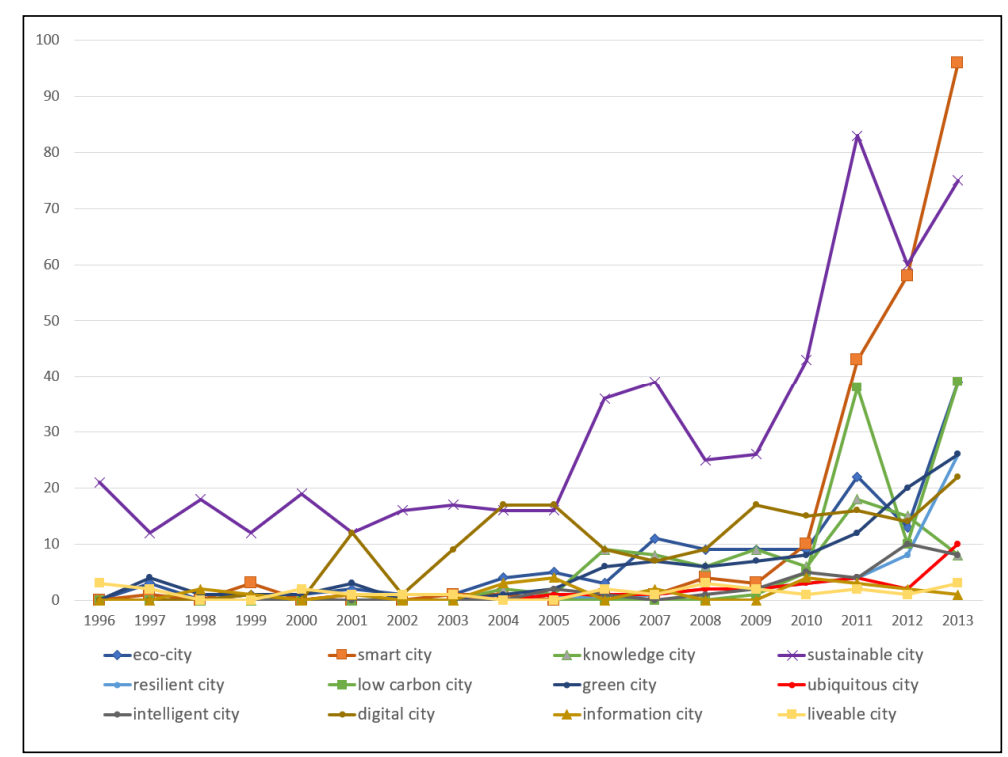

Source: edited by author, data source: Jong et al. (2015)

Although the timeline ends in 2013, the explosive growth of the occurrence of the smart city-related publications is clearly laid out, and by browsing the literature, we can expect this exponential growth to continue.

\section{The difficulties of making a definition}

On definition issues, almost every author of this topic points out immediately at the beginning of their articles that there is no unified, standardized smart city definition that would be accepted by everyone (Chourabi et al., 2012; Cavada, Hunt, \& Rogers, 2014; Albino, Berardi, \& Dangelico, 2015; Calzada, 2016; Z. Karvalics, 2016). There are different reasons for that, but the two most important ones are that on the one hand, we are talking about the combination of tools and systems, therefore, smart city is more like a label, a fuzzy concept, that only helps to avoid having to use complicated circumscriptions (Albino et al. 2015, p. 4). On the other hand, there is a wide range of professionals using this expression, whose

\footnotetext{
${ }^{4}$ About the methodology: the authors analysed the occurrence of twelve keywords: sustainable city, eco-city, low carbon city, liveable city, green city, smart city, digital city, ubiquitous city, intelligent city, information city, knowledge city, resilient city. From the two large databases, Web of Science and Scopus, the analysis was based on the articles in Scopus, since only that was fully compliant with the timeframe of the analysis (19962013). 1430 scientific articles were analysed in total.
} 
Gere, L.

viewpoints and aspects may differ significantly, therefore, every area of expertise highlights a little bit their understanding when they are talking about smart city solutions.

Concerning the almost infinite number of definitions, this article chose one that meets the following criteria: it is comprehensive, objective (which means that it is not a definition of any area of expertise, institution or corporation), and it is also known in the Hungarian literature - the author certainly did not want to create a new definition. The standardization and the establishment of an indicator system has already been started to measure and assess the effectiveness of the smart city instruments by the International Standardization Organization $^{5}$ (ISO), along with the British Standards Institution, and the article found the latter (BSI, 2014, p. 12.) the fittest to clarify the subject of this writing. According to this definition, the smart city means the "effective integration of physical, digital and human systems in the built environment to deliver a sustainable, prosperous and inclusive future for its citizens".6.

\section{The building stones of a smart city}

Beyond the definition of the smart city concept, one of the most active debates of this issue is the delineation of the development areas, in order to define in which areas the smart city developments can be applied the most effectively. Thus defined exact indicators can measure the "smartness" of the certain cities, they can be comparable and a ranking can be set up among them. Contrary to the diversity of definitions, the so-called "typologies" of subsystems appear unified apart from minor differences. The six main types of smart city developments based on the works of Cohen (2014) are: smart economy, smart environment (including energy issues), smart government, smart living (conditions), smart mobility and smart people ${ }^{7}$.

Caragliu et al. (2011, pp. 67-69) summarized the main characteristics of the "ideal" smart cities as well as smart city planning, which has been widely cited in the scientific literature, and often referred to, since its publication:

\footnotetext{
${ }^{5}$ For more details about the smart city ISO-standards please find the publication of the organization entitled ISO and Smart City (ISO, 2017) (http://www.iso.org/sites/worldsmartcity/assets/ISO-and-smart-cities.pdf), as well as the publication of Lechner Knowledge Centre (Lechner Tudásközpont), entitled Településértékelés és monitoring. Módszertani javaslat (Settlement evaluation and monitoring. Methodological recommendation) (only in Hungarian language) (Lechner Tudásközpont, 2015) (http://lechnerkozpont.hu/doc/okosvaros/telepulesertekeles-es-monitornig-modszertani-javaslat.pdf)

${ }^{6}$ This definition is also taken by Lechner Knowledge Centre, translated into Hungarian.

7 This typology is applied also by Lechner Knowledge Centre's Smart City Best Practice Collection (http://okosvaros.lechnerkozpont.hu/en), the EU Smart City Ranking (Giffinger et al. 2007) and the Smart Cities Council Index is also based on this typology.
} 
Gere, L.

1. Through its network infrastructure, a smart city can improve its economic and political efficiency and

2. enable the implementation of social-cultural and urban development (in this case the "infrastructure" includes business services, housing, leisure and lifestyle services as well as the ICT infrastructure).

3. There is strong focus on business-led urban developments (Hollands, 2008, p. 308).

4. To achieve equal access to public services for all urban residents is a fundamental objective (social inclusion).

5. The role of high-tech and creative industries in the long-term growth objectives of the cities are decisive (this aspect was a key issue of Richard Florida's [2002] works as well).

6. Great attention is paid to the role of social and relational capital in urban development. The role of continuous learning becomes increasingly important, since urban residents have to be able to use, apply, and in some particular cases, further develop the innovations, to make them really beneficial (UNCTAD, 2016, p. 10). In case this aspect is not given enough emphasis, it will inevitably lead to social polarization. (Therefore, in societies where this social capital is missing, strong emphasis should be laid on its development.)

7. Finally, the last main strategic component of smart cities is the social and environmental sustainability.

\section{THE SMART CITY-RELATED SCIENTIFIC DISCOURSE, A COMPARISON OF DOMINANT VIEWPOINTS}

Due to the variety of smart city-related concepts, it is easy to get lost in issues of the exact "parameters" of a smart city or the meaning of a smart city. These issues are addressed in many of the above-cited publications. At the moment - since it is a relatively new phenomenon -, the majority of scientific literature and other smart city-related writings (nonscientific articles, blog posts etc.) are examining this topic in the first place.

Perhaps it stems from this complexity of concepts and interpretations that most publications of this topic, besides definitional issues, deal with the critical analysis of the implementation of a smart city, with the conflicting opinions and viewpoints. This debate is not limited to the academic sphere, because it is a phenomenon that involves everyone as part of this progress; therefore, irrespectively of interests and areas of expertise, everyone becomes 
Gere, L.

part of the "discourse". The following part of the article tries to systemize these questions and critical remarks and describe them in detail, since taking these aspects into account may serve as a solid background for the preparation of any kind of smart city planning process.

\section{Technological utopia vs. technophobia}

The first comparison is part of a wider discourse, it is not limited only to the academic sphere, and certainly not just to the smart city instruments, but of course, includes them. In his research, Pintér (2004, pp. 15-30.) presented three different discourses related to the information society that perfectly fit for smart city developments as well; therefore, these three discourses would be presented briefly together.

The subject of the opposing parties' argument is that how the introduction of smart city instruments would impact on the residents' lives. Those who expect utopia through smart city developments, are, on the one hand, tech-companies and smart city-related businesses that are directly involved in (and will have profit from) the widest possible spread of these instruments and solutions (Townsend, 2013). A great number of analyses and estimations have been drafted on the market opportunities of smart city developments. Narrowly counted, it will be a $\$ 400$ billion market between 2015 and 2020, which can be over $\$ 1.5$ trillion in the same period (Deloitte, 2014). In addition, the estimations project a further growth after 2020. (The involvement of the tech-companies will be dealt with in detail below.)

On the other hand, to some extent, everybody tends to expect utopia, and in the $21^{\text {st }}$ century, people expect from technology the solution for their challenges. That is what Pintér (2004) writes about as the discourse of futurology-believers (its essence is that based on the technological innovations introduced in the $20^{\text {th }}$ century, the futurology-believers think that in the future, sooner or later, these will offer solutions to all our problems), while introducing the Athens model. The Athens model is the paradigm of technophiles, according to which "the technology is liberating and will increase the human well-being, resulted in a new electronic democracy - hence the name of the model: the direct democracy of the Greek city-state 2,500 years ago will make sense again in a new digital agora" (Pintér, 2004, p. 21). The smart city as the next step of human well-being appears also in one of the first smart city studies published in Hungary by the collaboration of HAS Centre for Economic and Regional Studies, West Hungarian Research Department (MTA RKK NYUTI) together with IBM, entitled „Smart Cities“ study (Lados-Horváthné Dr. Barsi, 2011). In this study, immediately by the definition issues the authors linked smart city to liveable city, and this approach is 
reflected throughout the whole study. It is a common phenomenon that today, concerning any urban paradigms (sustainable, green, eco-, knowledge-, liveable city etc.), they are to some extent about the exploitation of the new opportunities given by technological revolution. And in the broad sense, not only in relation with urban development, but practically, concerning every social-economic process today, according to the experiences with the rapid spread of technological innovation, visions of a better future are more popular than ever ${ }^{8}$.

However, besides the belief in the "omnipotence" of technology, there is also some kind of technophobia, the reluctance to use technological advances, which might become even more and more intensive. It originates in the fundamental human attitude that most of us fear "from the unknown, the new and from change" (Pintér, 2004, p. 17). This reluctance is not unfounded. Technology raises more and more security issues every day (cyber-security, protection and misuse of personal data etc.), and as technology is increasingly interwoven in city management, operation and monitoring of public services (among others), and more and more automatism is built in, in order to optimize these systems, the vulnerability of them also increases, and there is no guarantee that the control is "in good hands". Pintér (2004, pp. 2122) refers to that when presenting the Orwell model opposite to the Athens model, the believers of which claim that the new technology is intended to allow full control, in which humans play only subordinate role.

To reconcile the two extremely opposing viewpoints, Pintér proposes a solution, the socalled techno-realist approach, according to which, briefly, "more technology is not equal necessarily to a better, qualitatively improved society" (Pintér, 2004, p. 25); therefore, the solution is on the one hand the citizen's active participation in the innovation process (more details on that issue below), and on the other hand, the more versatile knowledge of the processes (the article hereby would like to contribute to this aim).

\section{A quick introduction, or wait and see?}

As it was mentioned in the introduction, cities play an increasingly important economic role and their economic performance is intensifying in the $21^{\text {st }}$ century. In addition, the urban residents' consumption exceeds the consumption of those who live in rural areas; therefore, cities mean important markets as well (as always in human history). City management also tends to work like the management of a big company, and cities compete with each other, just

\footnotetext{
${ }^{8}$ One example for that is Matt Ridley's recently published book, The Rational Optimist (Ridley, 2010)
} 
as companies are each other's competitors in the global market. In the operation of a city, cost-effectiveness and innovation are gradually gaining importance.

This discourse, compared to the previous one, has taken one step forward: its starting point (similarly to the author's) is that technological achievements will inevitably make a way for themselves in the cities, this process cannot and should not be restrained. Instead, the question is how this spread could be influenced, controlled or regulated by the cities (according to their own interests). The "pro" viewpoint in this discourse says that the best solution for the cities is to introduce the latest technological achievements as soon as possible so that they can set an example for other cities, and what is even more important, innovations make them more attractive to economic actors. Most of the technology-led new city developments (e.g. Songdo, Masdar City) were driven by that approach, to introduce cutting edge technologies, and thereby stand out from other cities. In the classic models about the diffusion of innovations these actors are the original innovators or early adopters (Kovács, 2004, p. 54).

On the contrary, the other side of this discourse - the early and late majority in the diffusion of innovations models (Kovács, 2004, p. 54) - has the position that at the moment cities should rather take time for considering the possible options before making a decision, introducing a certain technology only after proper preparation. The background of this approach is that because in most cases the introduction of new technologies is only a "pilot" phase, after that, those innovations are still revised, improved and developed. Therefore, for cities with limited resources ought to explore international practices, possible solutions, properly assess the local conditions and the exact needs of the residents, together with the expected impacts and results of the development, and only introduce the planned technology after that.

In case of smart city solutions, the continuous development of technology has special importance, there is no ultimate, universal solution (all the more so, because in a city the planning of certain public services has to meet the ever-changing needs, therefore, flexibility is of great importance $)^{9}$. And the certain challenges can be managed differently with the same efficiency, adapted to the local conditions. Furthermore, experience has shown that the

\footnotetext{
${ }^{9}$ The development of bike-sharing systems serves as a good example for that constant alteration. To store these bicycles, there are basically two models, the docking and the free-floating (you can leave your bike anywhere you want) systems. In Europe, first appeared the docking system, and in Budapest, this model was taken as a basis for planning the city's own bike-sharing service a couple of years ago. Since then, many cities around the world adopted the free-floating model, however, there is still no consensus on which one the optimal solution is. The latter's advantage is its flexibility, users are not limited to docking stations to leave their bicycles - but the argument against it says that in many cities the massive spread and the inappropriate use and storage of these bikes caused chaos in transport, land-use and urban design. (Source: interview with Péter Dalos, product manager of BKK BUBI, 12. 10. 2017)
} 
Gere, L.

uncritical adoption and application of uniformed solutions (exactly the same methods and procedures) in different cities is the least effective practice. This is one of the main critical observations against corporate-led developments, that the certain companies tries to apply a universal (or at least, they think it is universal) solution in as many cities as they can ( $\mathrm{Z}$. Karvalics, 2017, p. 16). Therefore, the proper preparation and planning, as well as the importance of having further development possibilities is highlighted by many sources (UNCTAD, 2016).

\section{The technology-driven vs. city-led/citizen-based smart city developments}

Having an extensive literature, this discourse is one of the hot topics in relation with smart city developments, or at least it has been, throughout the first couple of years after the emergence of the concept. The reason certainly is that the corporate sector is far more active in the research (and development) of smart city instruments in line with their profitorientation, the academic sphere, and it reacts much slower to the processes. But since the advanced co-operation of these two sectors is inevitable for the implementation of proper developments, the discussion already started in the early stages, and there is co-operation between companies and universities as well (e.g. Amsterdam Smart City initiative) (GereCzirják, 2016).

However, cities are still quite exposed to corporate interests, so the question arises: is a smart city the $21^{\text {st }}$-century, high-tech rebirth of Hall and Hubbard's (1996) entrepreneurial city, or is it really something more than that (Hollands, 2008)? The definition of smart city always refers to a higher standard of living and the resident's better well-being. However, concerning corporate thinking, they offer solutions to creating a better functioning, better operating city, in many cases absolutely ignoring the residents. Therefore, in the critical discourse, corporate/technology-driven developments always represent the lowest level, the least progressive approach of smart city developments.

Cohen (2015) has established a three-level planning hierarchy to illustrate the differences between the approaches.

The first and lowest level of the hierarchy is technology-driven development. In principle, it means that large transnational ICT-companies offer solutions to cities in order to increase their operational efficiency and improve their attractiveness, and the cities adopt them completely (uncritically), basically in order to increase their global competitiveness. On the level of technology-driven developments, companies sell their products, and cities are not yet 
fully aware of their actual social effects and their real impact on well-being - the only thing cities know is that they need these solutions. Songdo, South Korea and Masdar City, UAE are among the examples. Both cities are $21^{\text {st }}$ century "new cities" (technically city districts or quarters; Songdo/New Songdo is a new CBD in an existing city, and Masdar City is part of Abu Dhabi). As greenfield investments, they are completely planned, specifically with the purpose of creating cities combining the latest eco-friendly, sustainable, cutting-edge technologies. However, a high standard of living involves high housing costs, and the residents of these cities are rather selected, cannot be considered as "natural composition" in any case; moreover, the whole city works by an inverse logic: people fill in functions that are needed to operate the cities, and not the cities fill in social demands and needs.

In relation to Masdar City, Sassen (2012) wrote that it cannot be regarded as a real place to live at, only a real-time laboratory, where the operation of innovative urban solutions can be examined in lifelike conditions.

Townsend (2013) also writes critically about these kinds of development. His opinion is that the biggest problem of technology-driven futuristic urban visions is that they lose sight of the most important dynamics between the city and its inhabitants. ${ }^{10}$

The second level of Cohen's (2015) hierarchy is technology enabled, city-led developments. On this level, the city (led by the mayor and the city representatives) takes the lead in developing its own future, and it decides what role the smart technologies and innovations should play in the operation of the city. The city authority looks at technological innovations as tools for improving the quality of life (it has aims and vision how to use them, beyond their mere introduction). According to Cohen, most of the "leading" smart cities take place on this level (his examples are Barcelona and Rio de Janeiro).

The third and highest level (in this model) is citizen co-creation: the new generation of smart city developments. Citizens are actively participating in the development activities, social issues such as affordable housing or gender equality come to the fore. Citizen cocreation is based on equality and social inclusion, everything else is placed behind these principals. The starting point of the whole planning process is completely different as compared to the previous examples. Citizens can contribute to the developments through their ideas or can be involved as investors (for example in the citizen-level exploitation of renewable energy sources). In these cities, sharing-based initiatives are flourishing; however, it does not mean the corporates of platform economy (e.g. Uber or Airbnb) but rather the

\footnotetext{
${ }^{10}$ A more detailed description of the case of these two cities and their critical assessment can be found in GereCzirják (2016).
} 
small-scale initiatives such as neighborhood networks or bike-sharing systems. Examples include Medellín, Colombia besides the cities of the developed world (e.g. Barcelona, Amsterdam, Vienna, Vancouver).

Of course, citizen co-creation contributes to the developments efficiently only in societies that are mature enough for this process. Experience rather suggests that in many cases a citizen's participation is not prepared enough but it is more like a compulsory "task" during a development, and it is either used by NGOs as their tool of resistance (the expression is therefore associated with a negative meaning) or brings so many individual demands and aspects that it will no longer promote but block the given development. Therefore, citizens have to be involved in a coordinated way, in real co-operation with other actors (not as a conflicting group of interest). So far, it is easier to consider in theory than put into practice.

The disadvantages of technology-driven developments are clearly revealed from this hierarchy. Z. Karvalics (2017, pp. 16-20) is even more specific on this issue, as he summarized the problem-groups of the basic orientation of the smart city. Of these, five points are specifically related to the technology-driven developments: centralizationorientation, overrating technology, the - previously discussed - universalism, big citycenteredness, and business-driven approach.

Centralization-orientation refers to top-down developments, which are much more prevalent in relation with smart city developments, strengthening the over-planning and overregulation. It is a comfortable solution both for corporations and the city management, since their interest is to concentrate as much power in their hands as possible, but it is less desirable for residents, as it strengthens their vulnerability. During a proper smart city development a balance has to be found between top-down and bottom-up approaches (UNCTAD, 2016, Robinson, 2015). Big city-centeredness can also be related to centralization-orientation, as it means that companies interested in urban development will be the most active in big cities because of the economies of scale: the smaller a city is, the less it will "worth" to implement developments there. Of course, the demand to introduce smart city solutions is not necessarily related to settlement size; moreover, smart solutions can be applied in villages as well (and there are a lot of examples for rural "smart cities"); however, bottom-up initiatives are much more typical in these settlements.

Besides the ICT-producer and service companies, both the city management and the citizens tend to overrate technology. However, the responsibility of companies is bigger in the evolution of this set of problems because they consciously produce the visions, visuals and advertising materials through which they seek to increase the sale of their products and 
services, but at the same time often show a one-sided, utopian, unrealistic picture of the real opportunities of smart city instruments for the general (non-professional) audience. As Z. Karvalics writes, "the expectations about technology are not built on their real possibilities but on stereotypes, myths and promises" (Z. Karvalics 2017, p. 16).

Due to the business-driven approach, the communal and urban architectural aspects are more subordinate to the large companies and the market interests - claims Z. Karvalics (2017, p. 17). According to Hollands' (2015) argument, the different smart city-interpretations of different actors explain why residential interests are subordinated to corporate interests. Corporate visions imply that everyone will automatically benefit from the urban use of ICTtools, wealth and well-being will be distributed equally among all. However, it would mean the technological utopia mentioned above, which obviously cannot be realized but covers many social-economic challenges that could be managed only through people-centred, resident-focused initiatives ${ }^{11}$. Robinson (2015) writes that a smart city cannot be left to the market but cities themselves have to shape the market.

\section{The importance of social preparedness to introduce smart city tools}

The issue of social preparedness, on the one hand, is strongly related to the previous discourse, as its focus was on the comparison of technology-led and citizen-led developments (intentionally speaking less about citizen-led initiatives). On the other hand, it is an independent issue, which is worth paying special attention to. The inequality-raising effect of smart city programmes is a frequently occurring critical remark. In the midst of grand visions and strategic concepts, planners might forget whom they are planning the smart city for. Vanolo (2014) claims that the main problem with smart cities is that they serve only one welldefined group amongst their residents: the well-educated middle class. Far less emphasis is laid on marginalized groups, and that would (especially in the Global South) further increase the inequalities, instead of decreasing them. In addition to that, the observations on the competition between cities have also confirmed that those cities are more successful in the implementation of smart city programmes that have already shown such characteristics (Z. Karvalics, 2017, p. 19). In other words, this means that the already developed will develop faster and the underdeveloped will be lagging behind. Within the traditionally polarized

\footnotetext{
${ }^{11}$ The realization of one of the most grandiose business-driven smart city vision takes place in India in the framework of the 100 Smart City Mission initiative. More details about its background, and critical assessment in Gere (2017).
} 
societies, the fear of social exclusion increases significantly; among others, the 100 Smart Cities Mission in India is constantly criticized for that by planning experts (Gere, 2017).

The social capital, local know-how and the importance of lifelong learning already appear among the collected components of ideal smart city planning, stressed by many recommendations and guidelines. One of the UN's publications, dealing with smart city infrastructures (UNCTAD, 2016), highlights the existence of proper skills as a special challenge. It points out that implementing a successful smart city development requires proper human resources: "smart citizens" and not just "smart technology". Therefore, during the planning process, first the lack of skills to be supplemented has to be revealed. In education, more emphasis is needed on STEM subjects (Science, Technology, Engineering and Math). Already in primary education, these subjects should be made more attractive because the majority of workplaces will require technical skills in the future. There is a need for multidisciplinary approach in education, and the completion of more flexible, open, online classes and courses should be promoted. In order to train proper workforce, the private sector should co-operate with the public sector; partnership and collaboration is crucial ${ }^{12}$.

The same UN publication also draws attention to the threats of social exclusion during the planning process of smart city infrastructures. Many authors dealing with this issue (Pintér, 2004, Cséfalvay, 2017) highlight that there are losers of technological changes, who are not able or simply do not want to apply the latest technology; therefore, they are excluded from the benefits. In our rapidly changing world, this process forms the receivers of innovations into a group that should be managed with high priority, which requires a complex and multidisciplinary approach. Special attention should be paid to not excluding any social classes or groups from the beneficiaries of the developments. For this purpose, participatory governance should be enhanced and citizens should actively be involved in the decisionmaking process (UNCTAD, 2016, pp. 13-14). Corporate-led developments, in fact, erode this citizen activity, because by offering automated solutions to the problems, self-activity and self-organization decreases, and the spread of community solutions is less active (Robinson, 2015, cited by Z. Karvalics, 2017).

Consequently, it can be concluded that a smart city development can only be implemented successfully under proper technological conditions, advanced ICT-infrastructure and

\footnotetext{
${ }^{12}$ During the implementation of a smart city project, strong co-operation between the participating actors is important in every phase of the process, as well as the involvement of the citizens as development actors: it is the so-called quadruple helix model, developments through the co-operation of the universities/academic sphere, the industrial players, the government and the civil society/citizens. More about this issue in: Yawson, R. M. (2009), and EU (2016).
} 
Gere, L.

technological solutions. The other side, the "users" of smart applications, the urban citizens are just as important players. Further, urban planning could play a decisive role in properly assessing and completely revealing the existing needs of the society, and choose the development instruments in accordance with them.

\section{CONCLUSION}

This article aimed to reveal, summarize and evaluate the issues arising in relation with smart city developments. As the first step in this process, it identifies the trends proving why cities are becoming a more important factor than ever in managing the social-economic challenges in the $21^{\text {st }}$ century. It presents the most important demographic, technological, economic and city governance trends that fundamentally shape our cities in the new millennium.

After that, through the broadest possible presentation of the related literature, the article tries to reveal what it exactly means to be a smart city and why it is so complicated to find a definition for this concept. From new towns to other technology-related concepts, it goes over the evolution of the smart city concept, in order to contextualize it and the characteristics of using this paradigm. At the end of this section, the article briefly concludes the different types of smart city developments and some planning aspects.

The second part of the article presents the different mindsets in relation with smart cities through the international and Hungarian literature and reveals the dominant discourses of the issue: the basic attitudes toward smart cities, the possible approaches of the planning actors, the differences of corporate-led and citizen-led developments, and the emphasis of social preparedness. Through these discourses, it tries to illustrate that the views on smart city developments are far from being unified. Although, according to the dominant narrative, these solutions will have positive results in all respects, there are still many doubts about that. Nevertheless, since every participant thinks the final aim should be the achievement of real progress, the debate has a significant role because these developments could become more successful only through learning of as many viewpoints as possible.

\section{REFERENCES}

Albino, V., Berardi, U., \& Dangelico, R. M. (2015). Smart Cities: Definitions, Dimensions, Performance, and Initiatives. Journal of Urban Technology, 22(1), 3-21.

BSI (2014). BSI Standards Publication: Smart Cities - Vocabulary. The British Standards Insititution, February 2014.

Calzada, I. (2016). (Un)Plugging Smart Cities with urban transformations: Towards multistakeholder city-regional complex urbanity? URBS. Revista de Estudios Urbanos y 
Ciencias $\quad$ Sociales, 6(2), 25-45. Retrieved from http://www2.ual.es/urbs/index.php/urbs/article/view/calzada

Caragliu, A., Del Bo, C., \& Nijkamp, P. (2011). Smart Cities in Europe. Journal of Urban Technology 18(2), 65-82. DOI: http://dx.doi.org/10.1080/10630732.2011.601117

Cavada, M., Hunt, D. V. L., \& Rogers, C. D. F. (2014). Smart Cities: Contradicting Definitions and Unclear Measures. World Sustainability Forum 2014 - Conference Proceedings Paper 1-13. Petrieved from http://liveablecities.org.uk/sites/default/files/outcome_downloads/wsf4_smart_cities_dv lh_mc.pdf

Chourabi, H., Nam, T., Walker, S., Gil-Garcia J. R., Mellouli, S., Nahon, K., ...Scholl, H. J. (2012). Understanding Smart Cities: An Integrative Framework. 45th Hawaii International Conference on System Sciences, 2289-2297.

Cohen, B. (2014). The Smartest Cities In The World 2015: Methodology. [Html] Retrieved from https:/www.fastcompany.com/3038818/the-smartest-cities-in-the-world-2015methodology

Cohen, B. (2015). The 3 Generations Of Smart Cities - Inside the development of the technology driven city. [Html] Retrieved from https://www.fastcompany.com/3047795/the-3-generations-of-smart-cities

Cséfalvay, Z. (2017). TECHtonic Shifts. Kairosz Kiadó, Budapest, 2017.

Deloitte (2014). Monitor Deloitte - Smart cities... Not just the sum of its parts. [Pdf] Retrieved from https://www2.deloitte.com/content/dam/Deloitte/xe/Documents/strategy/me_deloittemonitor_smart-cities.pdf

Dobbs, R., Sven, S., Jaana, R., James, M., Charles, R., \& Alejandra, R. (2011). Urban world: Mapping the economic power of cities. McKinsey Global Institute.

Eremia, M., Toma, L., \& Sanduleac, M. (2017). The Smart City Concept in the 21st Century. Procedia Engineering, 181, 12-19. Special Issue: 10th International Conference Interdisciplinarity in Engineering, INTER-ENG 2016, 6-7 October 2016, Tirgu Mures, Romania. DOI: https://doi.org/10.1016/j.proeng.2017.02.357

EU (2016). Using the Quadruple Helix Approach to Accelerate the Transfer of Research and Innovation Results to Regional Growth. [Pdf] European Union, Commitee of the Regions. doi:10.2863/408040. Retrieved from https://cor.europa.eu/en/documentation/studies/Documents/quadruple-helix.pdf

Florida, R. (2002). Rise of the Creative Class. And How It's Transforming Work, Leisure and Everyday Life. New York: Basic Books.

Gere, L., \& Czirják, R. (2016). Erősítik-e a társadalmi kirekesztést a smart cityk? Információs Társadalom, 16(3), 83-100.

Gere, L. (2017). India, a country of change. PAGEO Geopolitikai Kutatóintézet. Retrieved from http://www.geopolitika.hu/hu/2017/11/17/india-gazdasagi-es-varosodasi-kihivasai/

Giffinger, R. C., Fertner, H., Kramar, H., Kalasek, R., Pichler-Milanovic, N., \& Meijers, E. (2007). Smart cities: Ranking of European medium-sized cities. [Pdf] Retrieved from http://www. smart-cities.eu/download/smart_cities_final_report.pdf

Hall, T., \& Hubbard, P. (1996). The entrepreneurial city: new urban politics, new urban geographies? Progress in Human Geography 20(2), 153-174. DOI: https://doi.org/10.1177/030913259602000201

Harrison, C., \& Donnelly, I. A. (2011). A Theory of Smart Cities. Proceedings of the 55th Annual Meeting of the ISSS, International Society for the Systems Sciences, Full Paper, $1-15$.

Hénard, E. (1910). The Cities of the Future. Royal Institute of British Architects, Town Planning Conference London, 10-15 October 1910, Transactions (London: The Royal 
Institute of British Architects, 1911, pp. 345-367.) [Html] Retrieved from http://urbanplanning.library.cornell.edu/DOCS/henard.htm

Hollands, R. G. (2008). Will the real Smart City Please Stand Up? Intelligent, Progressive or Entrepreneurial? City, 12(3), 303-320. DOI: 10.1080/13604810802479126

Howard, E. (1898). To-morrow: A Peaceful Path to Real Reform. [Pdf] Swan Sonnenschein \& Co., Ltd. Paternoster Sqaure, London. Retrieved from https://ia800504.us.archive.org/0/items/tomorrowpeaceful00howa/tomorrowpeaceful00 howa.pdf

ISO (2017). ISO and smart cities. International Organization for Standardization. Geneva, Switzerland. [Pdf] Retrieved from http://www.iso.org/sites/worldsmartcity/assets/ISOand-smart-cities.pdf

Jelinek, C., \& Pósfai, Z. (2013). Bevezetés: A városi önkormányzattól a városi kormányzásig. In Jelinek, C., Bodnár, J.. Czirfusz, M., \& Z. Gyimesi (Eds.), Kritikai városkutatás (pp. 145-154). Budapest: L'Harmattan Kiadó.

Jong, M. de, Joss, S., Schraven, D., Zhan, C., \& Weijnen, M. (2015). Sustainable-SmartResilient-Low Carbon-Eco-Knowledge Cities; Making sense of a multitude of concepts promoting sustainable urbanization. Journal of Cleaner Production, 109, 2538. DOI: 10.1016/j.jclepro.2015.02.004.

Khanna, P. (2016). Connectography: Mapping the Future of Global Civilization. New York: Random House.

Kovács, G. (2004). Innováció, technológiai változás, társadalom: újabb elméleti perspektívák. Szociológiai Szemle, 3, 52-78.

Lados, M., \& Horváthné Barsi B. (2011). „Smart cities” tanulmány. Győr: MTA RKK NYUTI - IBM.

Lux, Research (2015). Cities as Technologies: Using Data and Analytics to Grow From Smart to Brilliant. [Pdf] Retrieved from https://members.luxresearchinc.com/research/report/18361

Pintér, R. (2004). A magyar információs társadalom fejlödése és fejlettsége a fejlesztők szempontjából. PhD thesis. Budapest: Eötvös Loránd Tudományegyetem Társadalomtudományi Kar.

Ridley, M. (2010). The Rational Optimist: How Prosperity Evolves. HarperCollins Publishers.

Robinson, R. (2015). 6 inconvenient truths about Smart Cities [Html]. Retrieved from https://theurbantechnologist.com/2015/02/15/6-inconvenient-truths-about-smart-cities/

Sassen, S. (2012). Urbanising technology. Urban Age Electric City Conference, London 6-7 December 2012, 12-14 [Pdf]. Retrieved from https://files.lsecities.net/files/2012/12/theelectric-city-newspaper.pdf

Schwab, K. (2016). The Fourth Industrial Revolution: What It Means and How to Respond. Foreign Affairs Special Issue, 2-11.

Tosics, I. (2008). Nagyvárosi kormányzás: A város és környéke együttmüködése. Külföldi példák és a hazai relevancia. Tér és Társadalom, 22(1), 3-25.

Townsend, A. M. (2013). Smart Cities: big data, civic hackers, and the quest for a new utopia. New York: W. W. Norton \& Company, Inc.

UN (2015a). World Urbanization Prospects: The 2014 Revision [Pdf]. United Nations, New York. Retrieved from https://esa.un.org/unpd/wup/Publications/Files/WUP2014Report.pdf

UN (2015b). World Population Prospects: The 2015 Revision. United Nations, New York.

UN (2018). World Urbanization Prospects: The 2018 Revision [Pdf]. Key facts. United Nations, New $\quad$ York. $\quad$ Retrieved from https://esa.un.org/unpd/wup/Publications/Files/WUP2018-KeyFacts.pdf 
UNCTAD (2016). Smart cities and infrastructure. [Pdf] Report of the Secretary-General, United Nations Economic and Social Council, Commission on Science and Technology for Development. Retrieved from https://unctad.org/meetings/en/SessionalDocuments/ecn162016d2_en.pdf

Vanolo, A. (2014). Whose smart city? [Html] Retrieved from https://www.opendemocracy.net/opensecurity/alberto-vanolo/whose-smart-city

Yawson, R. M. (2009). The Ecological System of Innovation: A New Architectural Framework for a Functional Evidence-Based Platform for Science and Innovation Policy. In K. R. E. Huizingh, S. Conn, M. Torkkeli, \& I. Bitran (Eds.), The Future of Innovation. Proceedings of XX ISPIM 2009 Conference, Vienna, Austria.

Z. Karvalics, L. (2016). Okos városok: a dekonstrukciótól a hiperkonstrukcióig. Információs Társadalom, [S.1.], 9-22. DOI: http://dx.doi.org/10.22503/inftars.XVI.2016.3.1.

Z. Karvalics, L. (2017). Okos városok, kérdö- és felkiáltójelekkel. iASK - KRAFT könyvek sorozat. Szombathely: Felsőbbfokú Tanulmányok Intézete. 